\title{
THE EFFECT OF CHEMOKINE CXCL-13 ON THE CLINICAL AND FUNCTIONAL STATUS OF PATIENTS WITH MULTIPLE SCLEROSIS IN REMISSION
}

\author{
N.V. Sursiakova1, E.M. Kuklina ${ }^{2}$, T.V. Baidina ${ }^{1}$, I.V. Nekrasova ${ }^{2}$ \\ ${ }^{1}$ E.A. Vagner's Perm State Medical University, Perm, Russia; \\ ${ }^{2}$ Institute of Ecology and Genetics of Microorganisms, the Ural Branch of the Russian Academy of Science, \\ Perm, Russia

\section{ВЛИЯНИЕ ХЕМОКИНА СХСL-13 НА КЛИНИЧЕСКОЕ И ФУНКЦИОНАЛЬНОЕ СОСТОЯНИЕ ПАЦИЕНТОВ} \\ С РАССЕЯННЫМ СКЛЕРОЗОМ В СТАДИИ РЕМИССИИ
}

\section{Н.В. Сурсякова ${ }^{1}$, Е.М. Куклина ${ }^{2}$, Т.В. Байдина ${ }^{1}$, И.В. Некрасова ${ }^{2}$}

${ }^{1}$ ФГБОУ ВО «Пермский государственный медицинский университет им. акад. Е.А. Вагнера» Минздрава России. Кафедра неврологии им. В.П. Первушина, Пермь;

${ }^{2}$ «Институт экологии и генетики микроорганизмов Уральского отделения Российской академии наук» филиал ФГБУН Пермского федерального исследовательского центра Уральского отделения РАН, Пермь

Introduction. CXCL-13 can be involved in the development of MS, and its level in peripheral blood may have diagnostic and / or prognostic significance. The purpose of this study is to assess the level of CXCL-13 in serum and its relationship with the clinical and functional state of patients with remitting MS in remission. Materials and methods. The study involved 67 patients (28 men and 39 women) with a relapsing MS in remission. All patients were examined by scales and questionaries EDSS, Multiple Sclerosis Functional Composite, Multiple Sclerosis Impact Scale 29, Fatigue Severity Scale. On the day of the clinical examination venous blood samples were taken from patients and healthy donors, serum was isolated, and the level of CXCL-13 was assessed by enzyme immunoassay method. Results and discussion. It was revealed that CXCL-13 in the serum in patients with MS was significantly lower than in healthy volunteers. A relationship was found between serum CXCL-13 and the severity of neurological deficit according to EDSS, with walking speed of 25 feet, with an assessment of the quality of life and fatigue. Conclusions. Despite the association of CXCL-13 with the clinical and functional state of MS patients, at present time this chemokine cannot be considered to be a diagnostic or prognostic marker in MS patients.

Keywords: рассеянный склероз; хемокин 13; EDSS; MSIS 29; FSS.

Введение. CXCL-13 может быть вовлечен в развитие PC, а его уровень в периферической крови может иметь диагностическое и/или прогностическое значение. Цель настоящего исследования оценить уровень CXCL-13 в сыворотке крови и его связь с клиническим и функциональным состоянием пациентов с ремитирующим РС в стадии ремиссии. Материалы и методы. В исследовании приняли участие 67 пациентов (28 мужчин и 39 женщин) с ремиттирующим рецидивирующим типом течения РС в стадии ремиссии. У всех пациентов было проведено обследование по шкалам и акетам EDSS, Multiple Sclerosis Functional Composite, Multiple Sclerosis Impact Scale 29, Fatigue Severity Scale. В день проведения клинического обследования у пациентов и здоровых доноров были взяты пробы венозной крови, выделена сыворотка и оценен уровень CXCL-13 методом иммуноферментного анализа. Результаты. Выявлено, что CXCL-13 в сыворотке пациентов с РС достоверно ниже, чем у здоровых добровольцев. Обнаружена связь уровня CXCL-13 в сыворотке с выраженностью неврологического дефицита по EDSS, со скоростью ходьбы на 25 футов, с оценкой качества жизни по MSIS 29 и утомляемостью по FSS. Выводы. Несмотря на связь CXCL-13 с клиническим и функциональным состоянием больных РС, в настоящее время нельзя рассматривать данный хемокин в качестве диагностического или прогностического маркера при исследуемой патологии.

Ключевые слова: multiple sclerosis; CXCL-13; EDSS; MSIS 29; FSS.

Introduction. When studying the pathogenesis of multiple sclerosis (MS), more attention is paid to the role of B-lymphocytes in the development of this disease. The Chemokine CXC family 13 (CXCL-13), the chemokine receptor ligand CXCR5, is the main regulator of the transport of naive $\mathrm{B}$ cells, which initiates their migration into tissues (including the nervous system) and the formation of germinal centers [2]. Currently, CXCL-13 is considered to be a biomarker in many autoimmune diseases, such as systemic lupus erythematosus, polymyositis and ankylosing spondylitis [3]. Since MS is associated with intensive infiltration of the central nervous system by B-lymphocytes, CXCL-13 may be involved in the development of this pathology and the it's level in peripheral blood may have diagnostic and/or prognostic value. The purpose of this study is to assess the level of CXCL-13 in serum and its relationship with the clinical and functional state of patients with remitting MS in remission. 
The results of the examination of MS patients

\begin{tabular}{|l|c|}
\hline \multicolumn{1}{|c|}{ Index } & Me (LQ; UQ) \\
\hline 25 foot walking speed (MSFC), s & $4.55(4.2 ; 5.9)$ \\
\hline 9 hole-peg-dominant hand test (MSFC), s & $20.20(18.25 ; 23.5)$ \\
\hline 9 hole-peg-non-dominant hand test (MSFC), s & $21.45(19.35 ; 25.52)$ \\
\hline PASAT (MSFC), answers & $44(37 ; 50)$ \\
\hline Life quality assessment (MSIS29), points & $50(38 ; 73)$ \\
\hline Fatigue assessment (FSS), points & $29(14 ; 46)$ \\
\hline
\end{tabular}

Material and methods. The study involved 67 patients (28 men and 39 women) with a relapsing-remitting type of MS in remission. All patients had a reliably established MS diagnosis according to the Macdonald criteria (2010); the degree of disability on the Expanded Disability Status Scale (EDSS) was up to 6.0 points. The control group included 14 people without identified neurological disorders. Patients and healthy donors with signs of inflammatory diseases and pregnant women did not participate in the study. The average age of the patients was $33 \pm 6.5$ years, the disease duration was $6.5 \pm 3.9$ years, the frequency of exacerbations was $0.35 \pm 0.56$ times a year.

All patients were assessed for neurological status by EDSS scale, functional status by Multiple Sclerosis Functional Composite (MSFC, including 25 foot walk test, nine-well test and auditory test), quality of life of MS patients according to the Multiple Sclerosis Impact Scale 29 (MSIS 29), fatigue - by Fatigue Severity Scale (FSS). On the day of the clinical examination venous blood samples were taken from patients and healthy donors, serum was isolated, and the level of CXCL-13 was assessed by enzyme immunoassay (ELISA). Data processing was carried out using the program STATISTICA 10 using non-parametric methods (calculation of the correlation coefficient $R$ and $U$-criterion).

Results and discussion. The results of the examination of patients are presented in Table 1.

Significant difference in the content of CXCL-13 in the serum of patients with MS and healthy volunteers was revealed. In healthy donors, the content of CXCL-13 was $52.08(49.52 ; 76.15) \mathrm{pg} / \mathrm{ml}$, and in patients with MS - $39.96(23.53 ; 54.64) \mathrm{pg} / \mathrm{ml}$ ( $U=195, p=0.0008)$. The obtained results do not explain the available literature data on an increase of the chemokine level in the cerebrospinal fluid in patients with MS [4], however, they are consistent with the data from the pilot studies of K.R.Edwards and colleagues on the simultaneous assessment of the level of chemokines in serum and cerebrospinal fluid in patients with MS: the level of CXCL-13 in this work was increased in the cerebrospinal fluid in patients with MS compared to that in healthy donors, but decreased in serum [5]. Perhaps this effect is associated with the active capture of CXCL-13 by B-lymphocytes.

However, the correlation analysis revealed a relationship between serum CXCL-13 and severity of neurological deficit according to EDSS $(r=0.36$, $p=0.041)$, with a walking speed of 25 feet $(r=0.29$, $p=0.047)$, with the assessment of quality of life by MSIS $29(r=0.34, p=0.049)$ and fatigue by FSS $(r=0.31, p=0.039)$, which indicates the participation of this cytokine in the development of the disease. Similar information is described in literature - the level of CXCL-13 in organism is associated with the clinical and radiological activity of the disease [6]. Thus, despite the association of CXCL-13 with the clinical and functional status of patients with MS, its level in the serum of patients is lowered in comparison with healthy donors and does not reflect the concentration of CXCL-13 in the nervous tissue in MS, so, this chemokine can not be considered to be diagnostic or prognostic marker of MS.

\section{References}

1. Disanto G, Morahan J, Barnett M, et al. The evidence for a role of B cells in multiple sclerosis. Neurology. 2012;78(11):823-832.

2. Havenar-Daughton C, Lindqvist M, Heit A, et al. CXCL13 is a biomarker of germinal center activity. Proceedings of the National Academy of Sciences. 2016;113(10):2702-2707.

3. Shi G, Zhang Z, Li Q. New Biomarkers in Autoimmune Disease. Journal of Immunology Research. 2017;2017:1-2.

4. Ragheb S, Li Y, Simon K, et al. Multiple sclerosis: BAFF and CXCL13 in cerebrospinal fluid. Multiple Sclerosis Journal. 2011;7(7):819-829.

5. Edwards KR, Goyal J, Plavina, et al. Feasibility of the Use of Combinatorial Chemokine Arrays to Study Blood and CSF in Multiple Sclerosis. PLoS ONE. 2013;8(11):10-13.

6. Novakova L, Axelsson M, Khademi M, et al. Cerebrospinal fluid biomarkers as a measure of disease activity and treatment efficacy in relapsing-remitting multiple sclerosis. J. Neurochem 2017;141:296-304. 